\title{
Green Economy - Vector of Sustainable Development
}

\section{Zielona gospodarka - wektor zrównoważonego rozwoju}

\author{
Anar Ospanova*, Iryna Popovychenko**, Elena Chuprina ${ }^{\star \star *}$ \\ *Turan University, Department of World and National Economy, \\ Almaty, st. Satpayev 16, A15P4M6 (050043) Republic of Kazakhstan \\ E-mail: a.ospanova@turan-edu.kz, ORCID: 0000-0003-1789-105X \\ **Prydniprovs 'ka State Academy of Civil Engineering and Architecture, \\ Department of Economics and Entrepreneurship, \\ Dnipro, Chernyshevsky Street 24a, 49600 Ukraine \\ E-mail: popovychenko.iryna@pgasa.dp.ua,ORCID:0000-0003-3443-9356 \\ ***Donetsk State University of Management, Department of Marketing, \\ Mariupol, Karpynskoho, 58, 87513 Ukraine \\ E-mail: eochuprina@ukr.net, ORCID:0000-0002-9252-8114
}

\begin{abstract}
The article is devoted to the formation of theoretical, methodological foundations and the development of conceptual approaches to the practical provision of the green economy, considered as a vector of sustainable development. The study substantiates the need to create a new global economic school. The existence of two concepts of economic development of future generations is established. The author's vision of economic growth in the conditions of sustainable development is formed, as well as its necessity is also proved. A component model of sustainable development is proposed, which allows reflecting the essence and content of the green economy. The positive experience of green integration is summarized. The negative aspects on the way to the practical implementation of the Millennium Development Goals are identified.
\end{abstract}

Key words: sustainable development, Millennium Development Goals, economic growth, green economy, green technologies, green construction, green marketing, green tourism

\section{Streszczenie}

Artykuł poświęcony jest kształtowaniu podstaw teoretycznych, metodologicznych oraz rozwojowi koncepcyjnych podejść do praktycznego zapewnienia zielonej gospodarki, traktowanej jako wektor zrównoważonego rozwoju. Badanie uzasadnia potrzebę stworzenia nowej globalnej szkoły ekonomicznej. Ustala się istnienie dwóch koncepcji rozwoju gospodarczego przyszłych pokoleń. Kształtuje się autorska wizja wzrostu gospodarczego w warunkach zrównoważonego rozwoju, a także udowadnia jego konieczność. Proponowany jest składowy model zrównoważonego rozwoju, który pozwala odzwierciedlić istotę i treść zielonej gospodarki. Podsumowano pozytywne doświadczenia zielonej integracji. Zidentyfikowano negatywne aspekty na drodze do praktycznej realizacji Milenijnych Celów Rozwoju.

Słowa kluczowe: rozwój zrównoważony, Milenijne Cele Rozwojowe, wzrost ekonomiczny, zielona ekonomia, zielone technologie, zielone budownictwo, zielony marketing, zielona turystyka 


\section{Introduction}

The current conditions of humanity's existence indicate the presence of a number of problems that form a system of challenges for the progressive development of future generations. Such challenges include the systemic inconsistencies that have been formed between the processes of economic, social and environmental development. The traditional model of economic growth, due to its irrationality, faced an increasing set of social and environmental restrictions, which as a result led to the loss of its legal capacity. In this regard, there was a need to form a fundamentally different concept (sustainable development), a global socio-economic transition, which, along with a qualitative update of the technological base, increasing production efficiency and competitiveness, is designed to improve the quality of life and the living environment.

The concept of sustainable development contributed to the expansion of the range of scientific, methodological and applied tasks. In modern scientific literature, there is no universal categorical apparatus, there is no approved system of markers and indicators for assessing social, economic and environmental progress, there is no unified approach to solving the climate problem, including such an extreme point of view as non-recognition of the very fact of its existence. All this makes it difficult to develop practical strategic solutions for the implementation of sustainable development policies.

Despite all these differences, the vast majority of scientists believe that the material basis for the transition to a model of sustainable development is the formation and development of a specific eco-oriented sector in the structure of the economy - the green economy, which, unlike the traditional (brown economy), is based on the use of clean resource-saving technologies.

However, there is also no single vision in this area to date. Some authors consider the green economy as a process, others argue that it is a certain state. There is no universal methodology for assessing progress in the field of green economy, which could serve as a base for various countries. Moreover, the implementation of the basic principles of sustainable development, as well as the green economy, occurs at different speeds and on different scales in different parts of the world, which necessitates the generalization of experience that can be applied in an adapted form by other states. All of the above indicates the relevance and timeliness of the study submitted for consideration.

\section{Methodology}

The purpose of the study is to substantiate the theoretical, methodological foundations and develop conceptual approaches to the theoretical, method- logical and practical support of the green economy, considered as a vector of sustainable development.

The goal set made it necessary to solve the following tasks: to justify the expediency of creating a new global economic school, to form conceptual provisions regarding the category economic growth in the context of sustainable development, to expand the scientific vision of the essence and content of the green economy, to generalize positive world practices and identify the main lessons in the practical implementation of the green economy.

The object of the study is the process of interaction between the green economy and sustainable development.

The subject of the study is theoretical, methodological and practical approaches to the development of the green economy in order to implement the Millennium Development Goals, which are also the base for UN Sustainable Development Goals, introduced in 2015.

The work was based on theoretical and methodological approaches to the study of economic growth from the point of view of representatives of fundamental concepts: classical (P. Rosenstein-Rodan, R. Nurks, H. Leibenstein, A. Hirschman, G. Singer), neoclassical (A. Marshall, A. Pigou), Keynesian (J. M. Keynes), monetarism (K. Brunner, G. Simons, M. Friedman, I. Fischer), as well as the modern concept of sustainable development (K. Raworth, P. Erker). The paper uses the methodological experience of the study of the green economy and sustainable development (D. Pearce, E. Barbier, A. Markandia, S. Bobylev, N. Zubarevich, S. Solovyova, Y. Vlasov).

To substantiate the feasibility of creating a new global economic school, the article used both general scientific and economic methods of cognition: logical, inductive, deductive, statistical, graphical and tabular methods of interpreting information, methods of analysis, modelling, due to which the existence of two concepts of economic development of future generations was established, the essence of the concept of green economy was determined, a component model of sustainable development based on green economy was formed, the connection between the green economy and sustainable development was proved, conclusions were formulated.

The information and empirical base of the study was made up of official materials of European and international statistics (Eurostat, UN, World Bank, UNIDO, OECD, etc.), data from national and international analytical and research organizations, program and strategic documents regulating sustainable development and the development of the green economy at the international (UN), national (UNWTO, SROON, IFC World Bank Group) and regional levels (24/7 Wall Street, Miljönär, Avfall Sverige), other normative acts regulating the development of the green economy, data published in monographs, 
scientific journals, collections proceedings, conference materials, periodicals, including on the Internet.

\section{Findings and Discussion}

\subsection{On economic growth in the context of sustaina- ble development}

The development of a green economy requires, first of all, the creation of a new global economic school, since it is the eco-

nomic school that is the foundation on which the development of future generations is based. According to previous studies, the last economic school that allowed humanity to move to a new stage of development was the school of monetarists, which is based on the idea of the money supply as a determining factor in the formation of economic conditions, price levels, income, employment and macroeconomic equilibrium in general.

Speaking about monetarism, it should be said that the theories of American economists G. Simons, I. Fisher, F. Knight (20-40s of the twentieth century) had a significant influence on its formation. The activation of monetarism in the United States, as one of the varieties of neoliberalism, began in the late 40s and early $50 \mathrm{~s}$ of the twentieth century. The founder of the new economic theory of that period is considered to be the American economist K. Brunner, who used the category monetarism to define a general theoretical approach that recognizes the exceptional importance of money in the economy. Thus, monetarism, as a system of economic views, became an alternative to the neo-Keynesian concept due to its inability to solve the problems of economic development of the United States in the 50-60s.

The analysis of the studies of the formation and development of the monetarist economic school suggests that the intellectual leader of modern monetarism was the outstanding American economist, Nobel laureate Milton Friedman (1912-2006), whose main monetarist ideas are set out in the fundamental work Monetary History of the United States of 1867-1960 written in collaboration with Anna Schwartz. He formulated four theoretical postulates, which to a certain extent did not contradict the ideas of monetarism of K. Brunner, who claims that the money supply determines the economic situation (Brunner K., 1961) rather, they scientifically expanded the boundaries of the idea of monetarism: economic growth is achieved both with rising and falling prices, provided that their growth is moderate and predictable. From the last statement, it fol-

lows that in addition to the general theoretical approach, the authors already interfere with the applied aspect, namely, monetary policy in the economy (Friedman M., Schwartz A., 1963).

After a while, among the adherents of the monetarist school there were also those who did not quite share the classical (Friedman's) approach. For example, Peter Temin expressed doubts about the Friedman's causes of the crisis of the 1930s in America, denying the claim that most of them were of endogenous origin. This point of view is reflected in the works of the monetarist Paul Krugman, who said that the financial crisis of 2008 , like the crisis of the $30 \mathrm{~s}$, showed that central banks could not control the broad money supply, and this money supply was little related to GDP, respectively, the Federal Reserve System could not prevent the Great Depression, as stated by M. Friedman. Against the background of dramatic events in the economy and economic policy, several varieties of monetarism were formed with their own doctrines, models, as well as a new direction was formed - global monetarism.

As we can see, the period of the formation and development of monetarism was characterized by the emergence of a number of theories that explained the nature of cyclical development and offered stabilization options. Drawing parallels with the present time, it should be noted that a similar situation is observed. Economists around the world, realizing the need to form a fundamentally new economic school, create separate fragmented theories and models that often contradict each other, generating a discussion of both theoretical and applied nature.

Generalization of scientific research in the field of sustainable development allowed us to establish the existence of two concepts of economic development of future generations. According to one of them, it is necessary to overcome economic growth. So in the study, Kate Raworth says that the modern world has made extraordinary progress. However, the big problems that threaten the well-being of people have not disappeared anywhere. Unfortunately, the current economic thinking does not take this into account, so it needs to be transformed in accordance with the realities of the XXI century. It is important to note that the author focuses not on stopping economic growth in general, but on reducing the consumption of material goods (Raworth K., 2019).

Another concept is polar opposite to the first one, according to which economic growth cannot be stopped. The founders of the theory of economic growth are P. Rosenstein-Rodan, R. Nurks, H. Leibenstein, A. Hirschman, G. Singer. Among the contemporaries who assert the need for economic growth, as well as the fact that it (economic growth) is not the cause of the deterioration of the ecological state, is P. Erker. The scientist provides basic statistical data as evidence, according to which, with the growth of the UK GDP by $40-50 \%$, there was also a reduction in emissions of $\mathrm{CO}_{2}$ to $30 \%$ (Erker P., 2004). The most up-to-date data on the volumes of $\mathrm{CO}_{2}$ in the country context are presented in the annual report of BP Statistical Review of World Energy, according to which the total volume of carbon dioxide emissions in the world in 2019 reached 34.2 billion tons, i.e. increase of $1.1 \%$. At the same time, the largest percentage of emissions is accounted for by countries with developing economies $(+2.4 \%)$, 
Table 1. The essence of the concept Green Economy (Pearce, Barbier and Markandia, 1991; UNEP, 2009, Nairobi, 2011; The green economy, 2011; A guidebook to the Green Economy, 2011; ICC, 2012; Building an Equitable Green Economy, 2013; Green economy transition approach, 2013)

\begin{tabular}{|c|c|}
\hline Definition of Green Economy & Source \\
\hline $\begin{array}{l}\text { The green economy is an economy that should come to the aid of environmental policy. } \\
\text { The essence of the green economy has not been revealed. }\end{array}$ & $\begin{array}{l}\text { David Pierce, Edward Barbier } \\
\text { and Enil Markandia }\end{array}$ \\
\hline $\begin{array}{l}\text { The green economy is an economic activity related to the production, distribution and } \\
\text { consumption of goods and services that lead to an improvement in the well-being of } \\
\text { people in the long term, at the same time, without exposing future generations to signif- } \\
\text { icant environmental risks and reducing the shortage of environmental resources. }\end{array}$ & $\begin{array}{l}\text { UNEP, United Nations Envi- } \\
\text { ronment Programme }\end{array}$ \\
\hline $\begin{array}{l}\text { A green economy is an efficient economy based on low-carbon development that leads } \\
\text { to improved human well-being and social justice, while significantly reducing environ- } \\
\text { mental risks and preventing the loss of biodiversity. }\end{array}$ & $\begin{array}{l}\text { UNEP Summary report for rep- } \\
\text { resentatives of government } \\
\text { structures in Nairobi }\end{array}$ \\
\hline $\begin{array}{l}\text { A green economy is an economy that seeks long-term social benefits in short-term activ- } \\
\text { ities and leads to improved human well-being and reduced inequality, without exposing } \\
\text { future generations to significant environmental risks and environmental deficits. }\end{array}$ & $\begin{array}{l}\text { UNCTAD, United Nations } \\
\text { Conference for Trading and De- } \\
\text { velopment }\end{array}$ \\
\hline $\begin{array}{l}\text { The green economy is an economy that includes new sectors of the economy and should } \\
\text { become an important starting point for large-scale economic empowerment, meeting the } \\
\text { needs and providing opportunities to enterprises that pay more attention to social de- } \\
\text { velopment. }\end{array}$ & Government of South Africa \\
\hline $\begin{array}{l}\text { A green economy is a sustainable economy that provides a better quality of life for eve- } \\
\text { ryone within environmental constraints. }\end{array}$ & Coalition for a green economy \\
\hline $\begin{array}{l}\text { A green economy is an economy in which economic growth and environmental respon- } \\
\text { sibility mutually reinforce each other, while simultaneously supporting progress and so- } \\
\text { cial development. }\end{array}$ & $\begin{array}{l}\text { International chamber of com- } \\
\text { merce }\end{array}$ \\
\hline $\begin{array}{l}\text { The green economy is not a state, but a process of transformation and constant dynamic } \\
\text { progress that eliminates the systemic distortions and dysfunctions of the current econ- } \\
\text { omy and leads to well-being and equal access to opportunities for all people, while en- } \\
\text { suring the preservation of environmental and economic integrity. }\end{array}$ & Danish Group 92 \\
\hline $\begin{array}{l}\text { A green economy is an economy that focuses on using opportunities to simultaneously } \\
\text { advance economic and environmental goals. }\end{array}$ & $\begin{array}{c}\text { United Nations commission on } \\
\text { sustainable development }\end{array}$ \\
\hline $\begin{array}{l}\text { A green economy is an economy in which public and private investments are carried out } \\
\text { in order to minimize the impact of economic activities on the environment and where } \\
\text { market problems are eliminated through proven policies and legal frameworks aimed at } \\
\text { systematically taking into account the state of ecosystems, managing associated risks } \\
\text { and stimulating innovation. }\end{array}$ & $\begin{array}{l}\text { European Bank for Develop- } \\
\text { ment and Reconstruction }\end{array}$ \\
\hline
\end{tabular}

while the countries of the European Union (including the UK) have reduced emissions by $3.9 \%$ (BP Statistical Review of World Energy, 2020). The growth in the volume of garbage processing has grown from $4 \%$ in the $80-90$-ies, to $44 \%$ today. Thus, with a global view, it turns out that scientists, expressing different points of view, are talking, in fact, about the same concept. Someone calls it a green economy, someone calls it a carbon economy, due to the lack of a generally accepted concept. Taking into account the fact that the economy in its classical sense is a set of production relations corresponding to a given stage of development of the productive forces of society (Cambridge Dictionary online, 2021) it would be wrong not to talk about economic growth. It is worth talking about it, but from the perspective of current trends.

So, in the context of the formation of a holistic conceptual economic form that will bring civilization to a new level of development, economic growth is called such growth, which is provided not only by technology, but to a greater extent by intelligence (human capital). The more intelligence we invest, the higher the cost of the finished product, which means the higher the level of GDP and the welfare of the population. Taking into account the cyclical nature of the economy, this dependence will be repeated, which in turn will ensure sustainable economic growth.

According to the basic laws of economics, economic growth is carried out in two ways: intensive (quantitative) and extensive (qualitative). Quantitative growth is an infinite material growth that should recede into the historical distance. The new global economy should be based on qualitative growth due to intelligence (Boichenko, Martynovych, Shevchenko, 2021). In addition to the theoretical basic concept of economic development in the XXI century, it is necessary to form a methodological support for assessing the level of sustainable development in all its components. All this will make it possible to practically implement the principles, tasks and millennium development goals.

\subsection{About the green economy and sustainable devel-} opment

The discussion about the need to form a fundamentally new approach to further economic develop- 


\section{SOCIAL PROGRESS}

\section{ECONOMIC DEVEL-} OPMENT
Result: Reducing inequality and shared responsibility
Result: Increased efficiency of resources used

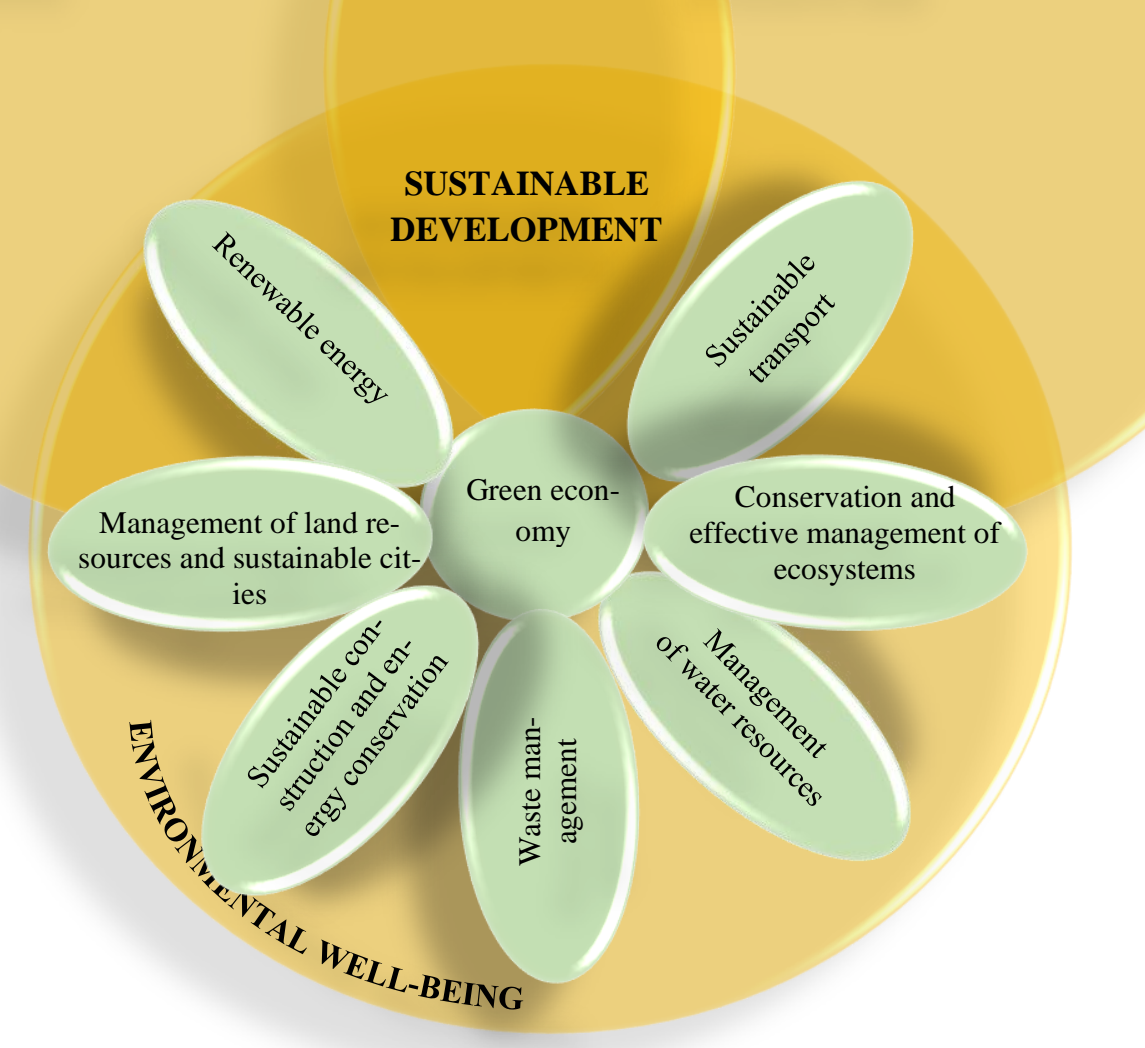

Figure 1. Component model of sustainable development based on the green economy

ment, which is not limited only to material or monetary resources, has been conducted for more than a dozen years. Despite this, to date, there is still no generally accepted theory of future development in the world, but one of the vectors has been identified, the name of which is green economy. According to the green growth concept of the Organization for Economic Co-operation and Development (OECD), the promotion of economic growth and development should be carried out under the condition of preserving natural assets and uninterrupted provision of ecosystem services on which our well-being depends (OECD). It follows from this definition that the green economy is the engine of economic growth. The analysis of the existing terminology has shown that the essence of the green economy is not limited only to growth (Table 1).

The green economy is considered as a process of transforming dynamic progress, promoting eco- nomic and environmental goals, minimizing the impact of economic activity on the environment, developing an efficient economy, etc.

The analysis of the basic normative documents in the field of sustainable development allowed us to come to the conclusion that the presented definitions reflect the actions (process) that determine the state of the triad of sustainable development and involve focusing efforts on the implementation of the Millennium Development Goals (Fig. 1).

The authors consider renewable energy; sustainable transport; sustainable construction and energy conservation; management of water resources; waste management; management of land resources and sustainable cities; conservation and effective management of ecosystems as actions that determine the state of the triad of sustainable development.

Since renewable energy sources are significantly safer for ecosystems, as well as economically profit- 
able, the green economy contributes to the implementation of the Sustainable Development Goals for each component (environmental, economic and social ones). For example, providing access to affordable, reliable, sustainable and modern energy sources contributes to the creation of a solid infrastructure, ensuring inclusive, sustainable industrialization and innovation, which in turn contribute to steady, inclusive and sustainable economic growth, full and productive employment, decent work for all, this increases the well-being of the population, reduces inequality and encourages shared responsibility.

Developed infrastructure and transport have a significant impact on the environment and account for $20 \%$ to $25 \%$ of global energy consumption and carbon dioxide emissions. According to the statistical review of world energy, almost $97 \%$ of emissions are generated as a result of direct burning of fossil fuels (BP Statistical Review of World Energy 2020). Therefore, sustainable, environmentally friendly transport contributes to reducing emissions, which in turn reduces the greenhouse effect, thereby contributing to the fight against climate change and its consequences, ensuring the well-being of future generations.

Sustainable construction and energy conservation contributes to the environmentally responsible and efficient use of resources throughout the entire life cycle of a construction object (planning, design, construction, operation, maintenance, repair, demolition). Existing environmentally friendly facilities have a positive impact on the health of residents, which ensures the openness, safety, resilience and sustainability of cities and settlements.

Green management of water resources contributes to the protection, restoration of terrestrial ecosystems, promotes their rational use, combating desertification, stopping and reversing the process of land degradation and stopping the process of loss of biologi cal diversity. Thus, in 1986, one of the worst droughts in history occurred in the Indian state of Rajasthan, which led to famine. After this disaster, local residents, teaming up with the scientific and industrial association, created water collectors and engaged in partial regeneration of the soil and forests of the region. As a result, the forest cover has increased by more than $30 \%$, the groundwater level has risen by several meters, and the productivity of arable land has increased (UN, 2020). This increased yields and contributed to the elimination of hunger, ensuring food security, improving nutrition, promoting the development of sustainable agriculture.

Management of water resources is closely related to the management of land resources. Land resources are used for various purposes, which include organic agriculture, forest restoration and ecotourism. Healthy woodlands replenish groundwater reserves by passing water through their roots and at the same time filtering drinking water for millions of people around the world. Green spaces contribute to the fight against drought, fires, coastal flooding, landslides and erosion. In addition, trees contribute to the provision of natural air conditioning. Thus, according to American studies, the shade from trees can reduce the cost of air conditioning of detached houses by $20-30 \%$ (Arthur Gutenberg, 1955) this, in turn, ensures rational consumption and production, resilience and sustainability of cities and settlements.

Waste management involves its collection, transportation, recovery and disposal, including control over these operations, as well as supervision of waste disposal sites, including operations performed by sellers and intermediaries (Directive 2008/98/EC). Waste management helps to reduce the adverse impact of waste on human health and the environment. If the traditional economy combines labor, technology and resources to produce end-use goods and waste, then the concept of a green economy is based on the principle of a healthy planet, which involves the return of waste back to the production cycle. Currently, there are about 200 names of various wastes, classified according to different characteristics: by origin, by composition, by aggregate state, by hazard class, by type, etc. Accordingly, depending on the type of waste, there are also various methods of sorting and processing. It should be noted that in the countries of the European Union there is a steady increase in the amount of waste (Fig. 2).

Thus, in 2018, 812 million tons of waste were generated in the EU, not counting basic mineral waste, which corresponds to 1,828 kilograms $(\mathrm{kg})$ of waste per capita (Eurostat). Of these wastes, $7.9 \%$ were hazardous to health or the environment, which corresponds to $143 \mathrm{~kg}$ per one citizen (Eurostat). Another $8.5 \%$ was food waste generated during the production, distribution and consumption of food, which in general amounted to 69 million tons or $154.6 \mathrm{~kg}$ per capita in 2018 (Eurostat). In the period from 2004 to 2018, the amount of non-mineral waste generated per capita in the EU increased by $1.0 \%$, and for the period of 2014-2018 this indicator increased by $4.8 \%$. This trend is associated not only with the growth of consumption in the European Union, but also with the refusal of China and other Asian countries to accept 24 categories of waste in 2018 (Reuters).

In this regard, the component model of sustainable development contributes to the solution of theoretical and methodological problems. It allows us to reflect the essence and content of the green economy, the meaning of which is to combine the process and the state, and consider them simultaneously, without separating them from each other, since all the components of sustainable development and the green economy are in constant dynamics and interaction. In addition, based on the proposed model, approaches to sustainable development indicators were systematized and work is underway to create a classification of green economy indicators. 


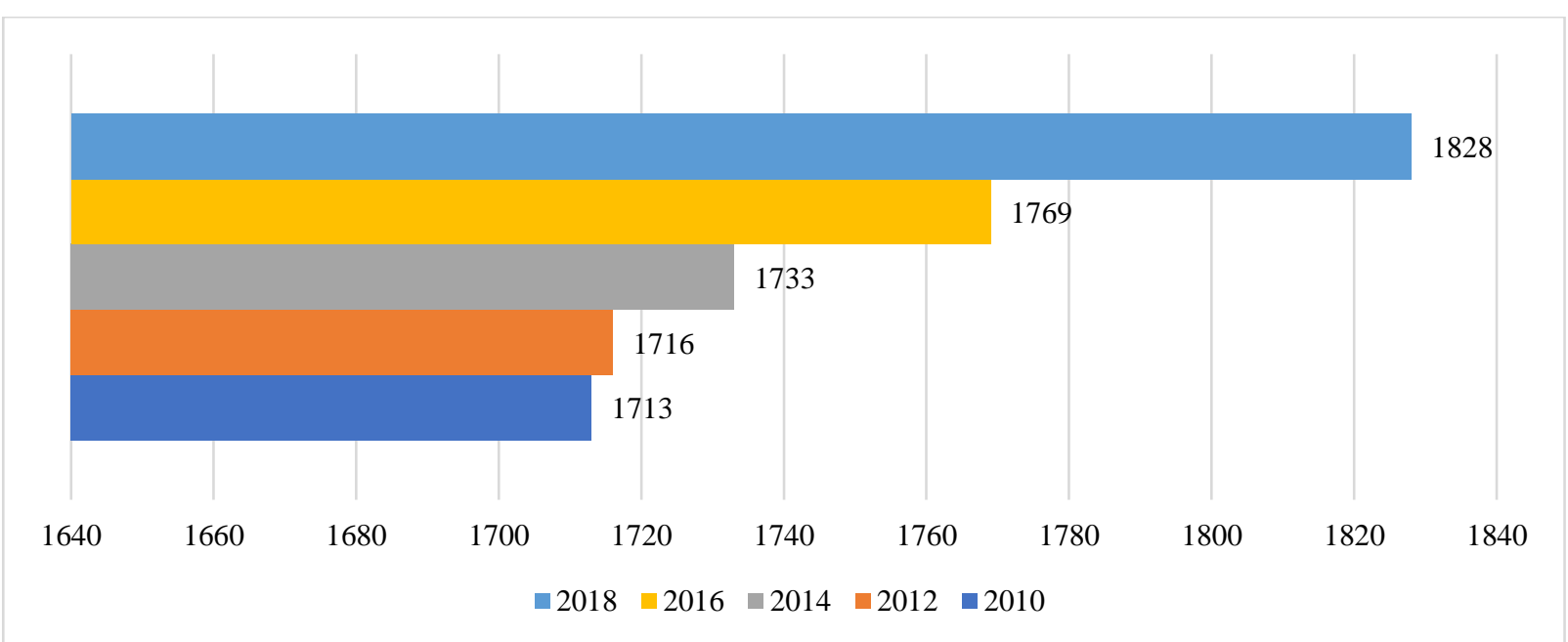

Fig. 2. Waste generation in the EU, with the exception of large mineral waste by hazard level, kg per capita for 2010-2018 (Eurostat)

\subsection{General-to-specific approach}

As already noted above, all countries are different in their potential, and, accordingly, in their level of development, so it is impossible to make the transition to sustainability on the whole planet at the same time. These are consistent, balanced decisions involving various spheres of activity, with a financial component, on the basis of which each state will have its own life cycle of transition. There are countries that have already achieved tangible results on the path to sustainable development, there are those, however, that are just taking the first steps. Against this background, there is a need to generalize the existing experience of green integration, to establish positive and negative aspects on the way to the practical implementation of the Millennium Development Goals.

\subsubsection{Green tourism}

The United Nations Environment Programme (UNEP) has identified ten key sectors for the transition to a green economy: agriculture, housing and utilities, energy, fisheries, forestry, industry, tourism, transport, waste disposal and recycling, as well as management of water resources. Due to the fact that tourism permeates and integrates all spheres of life and the vast majority of sectors of the economy (construction, trade, transport, accommodation, food, etc.), since it employs more than 320 million people, and its share in global GDP before the pandemic was 3.3 (10.4 percent) trillion U.S. dollars, we consider it appropriate to pay attention to this area in more detail (WTTC).

In the presented study, the authors understand under tourism in the context of a green economy such tourism activities that fully take into account the current and future economic, social and environmental impacts, as well as the preferences of consumers of services, industry and local communities (UNEP, UNWTO World Tourism Organization).
Regular research in the field of tourism (Anar Ospanova) allowed us to come to the conclusion that the green tourism market requires clearly defined organizational, economic and managerial foundations of both general theoretical and applied nature, since the vector of greening for tourism is also new. Based on this, there is a need to eliminate the content imperfections of the categorical apparatus, determine the goals of tourism taking into account new challenges and development trends, etc.

On the other hand, changes in the market structure, including due to the pandemic, together with systemic problems in tourism that both scientists and practitioners have been trying to solve for many years, have led to a number of applied consequences, such as: low level of dissemination of effective global green tourism practices, spontaneity and fragmentation in the provision of green services, imperfect financial and pricing policy in the field of green tourism, insufficient development of tourism marketing and management of the green services sector, etc. In the current situation, it is advisable to generalize the existing experience in the formation and implementation of mechanisms for providing green tourism services, taking into account current needs. Analysis of scientific publications in the field of green tourism (D. Zakirova, D. Ulanov, A. Church, T. Coles, R. Fish, A. Fyron, S. Vorobchuk, A. Kharin, D. Erov, M. Rutinsky, Y. Zinka, B. Finogeeva), allowed us to establish that the main reason for the intensification of its development in Europe is the crisis in the agricultural sector, generated by mechanization and modernization, which displaced manual labor. Thus, in the vast majority of rural regions of Europe, agriculture has ceased to be the most important form of land use and job creation. While the tourism sector was diametrically opposed to becoming popular and gaining momentum in development.

Despite the fact that during the pandemic, tourism in the EU decreased by $61 \%$ (Eurostat), according to 
WTO statistics, in 2019 France, Spain, Italy and Germany entered the top ten world destinations, and green travel amounted to 7 up to $20 \%$ of total travel (UNWTO). According to experts, from 0.5 to 0.9 million jobs are associated with green tourism. More than 2 million placements are concentrated in rural estates (Eurostat).

For Kazakhstan, the generalization of the European experience in the development of green tourism as a vector of sustainable development is valuable both from a theoretical and practical point of view. The same as for Europe, the experience of Kazakhstan can be useful, since certain developments in this regard has already been made. Thus, a large-scale green project for the development of green technologies was created on the basis of the Kazakh village of Arnasay, which involves teaching children at school based on the principles of sustainable development and the use of green technologies in everyday life. Arnasay schoolchildren conduct research on the introduction of green technologies as part of the general education process, and parents apply these technologies in their gardens and vegetable gardens in a practical way. In 2018, within the framework of the project Arnasay - Center for Green Technologies, the Coalition for Green Economy and Development of G-global in Kazakhstan allocated drip irrigation systems, agrofibre and hydrogel on a free basis, thereby laying the foundations for the development of family green entrepreneurship. Thus, for a short time, 60 thousand households have deployed new agricultural technologies, and the economic effect only from the developments of the Vyacheslavsky school amounted to 4.5 million tenge per year (10,583 US dollars) (Green Economy. Green technologies).

Based on the experience of European states, on the territory of Arnasay, taking into account its potential (advantageous geographical location, natural potential, good transport interchange and the development of green infrastructures) there are great prospects for the development of various types of green tourism all year round. In this regard, the expediency of using is the experience in the gastronomic tourism of Italy and Austria, because on the territory of Arnasay vegetables are grown all year round, a closed water supply installation for growing fish works, which ensures the obtainment of environmentally friendly products. According to the experience of Austria, it is possible to organize green herb collection tours in Arnasay. Taking advantage of the experience of Finland, which is based on recreation on the shores of protected lakes and rivers, recreation on the Vyacheslavsky reservoir can be turned into an allseason one by equipping it with farmsteads based on the experience of Spain, and on the basis of the British and Ukrainian experience, by organizing Christmas green tours. In Germany, green tourism involves participation in international fairs and trade shows, this experience can be depleted with gastronomic tours, and within the framework of the Kazakh Cuisine festival Toikazan, an autumn gastronomic eco tour can be organized.

Thus, green tourism, as one of the sectors of the transition to a green economy, contributes to ensuring economic development, environmental well-being and social progress. At the same time the exchange of experience (not only in the tourism sector) will allow us to take into account the negative aspects and apply the positive aspects towards the implementation of the Millennium Development Goals.

\subsubsection{Green construction}

According to the California Department of Resources Recycling and Recovery, construction waste, in comparison with other types of waste, poses the greatest threat to the environment, which means that it requires greater focus on its disposal (CDRRR, 2020). This point of view is reflected in the studies of the IPIT Design Institute, where it is noted that the evolution in the field of construction technologies, the production of new materials encourages builders and designers to be more versatile, as well as to make bold and extraordinary decisions. The construction industry strives to meet the high requirements of the current consumer. At the same time, the development of construction entails an increase in the negative impact on the environment (IPIT, 2021). In this vein, during the construction of a 100-apartment building, an average of 15-20 tons of solid waste is formed, the bulk of which is broken bricks, the remains of hardened concrete and mortar, the remains of wall blocks made of expanded clay concrete, cellular concrete, drywall, foam, mineral wool, etc. From one old five-story building, an average of 3,000 cubic meters of construction and repair waste is generated (Property Times, 2018).

In addition, buildings around the world use about $40 \%$ of all primary energy consumed, $67 \%$ of all electricity, $40 \%$ of all raw materials and $14 \%$ of all drinking water supplies, as well as produce $35 \%$ of all carbon dioxide emissions and almost half of all solid urban waste (ICS Group, 2021).

It should be noted that 11-13 million tons of solid household waste (SHW) are generated annually in Ukraine. On average, there are about $300 \mathrm{~kg}$ SHW per person annually (IFC). According to the study conducted by 24/7 Wall Street, Ukraine in 2019 entered the top ten countries that produce the most garbage per capita (Fig. 3).

The increase in waste generation is due to an increase in the welfare of society. The level of SHW processing in Ukraine is 7-8\%, while in the countries of the European Union (EU) up to $60 \%$ of SHW waste is processed (Eurostat). Therefore, in Ukraine, more than $90 \%$ of SHW is sent to landfills and unauthorized landfills. If this situation persists, then taking into account the overcrowding (5-7\% of the total number of authorized landfills), the closure and reclamation of environmentally unsafe landfills 


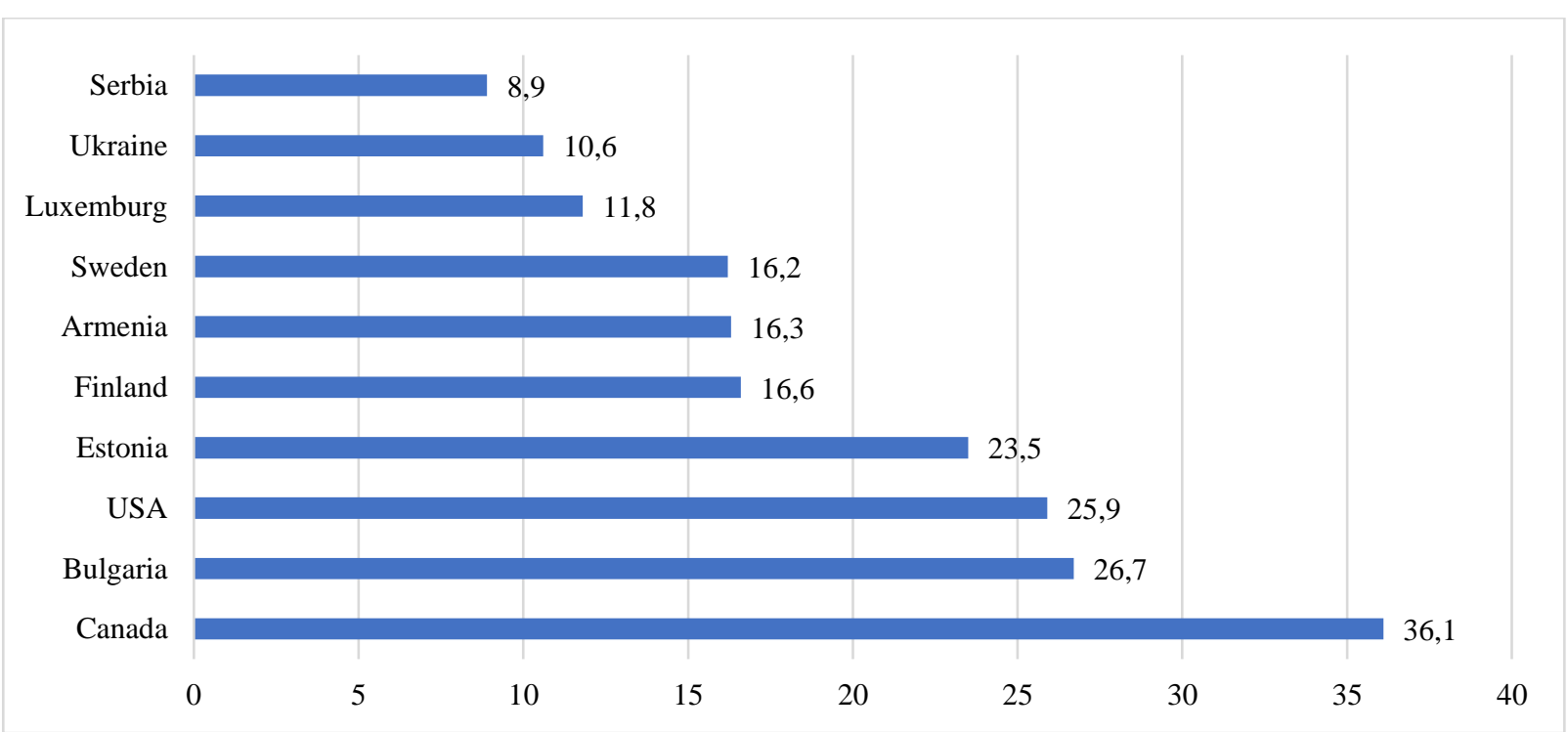

Fig. 3. Rating of countries with the largest amount of garbage per inhabitant for 2019 , tons (24/7 Wall Street)

(16\%), the need to allocate land for landfills will increase (IFC).

According to the Ministry of Regional Development and the Ministry of Natural Resources of Ukraine, there is the need for the construction of at least 650 new landfills. Independent experts estimate the territories occupied by landfills at 12 thousand square kilometres, which exceeds the territory of Montenegro and Cyprus and is significantly higher than the official estimate of 100 square kilometres (IFC).

The current situation has a negative impact not only on the atmosphere, soil, groundwater and soils, it also negatively affects the flora and fauna, worsens the quality of life of the population living in nearby settlements. As a result of the lack of a system for the separate collection and disposal of waste containing toxic components, environmental pollution with dangerous substances is increasing.

In addition to environmental problems, irrational management of SHW generates a number of economic benefits lost. Thus, according to the UNDP Ukraine could receive income in a single year from the disposal of paper in 180 million UAH, plastic 740 million UAH, metal - 225 million UAH, which, in general, with regard to the generation of heat and power, would have amounted to 1.3 billion UAH (€130 million) (IFC).

The Government of Ukraine has recognized the management of solid waste as the most urgent and critical problem that should be solved within the framework of the implementation of the strategy for sustainable development until 2030 on the basis of programs for the implementation of green technologies in practical life. Among the main reasons for low initiative in waste disposal are insufficient funding and lack of experience.

Despite the fact that Sweden is ahead of Ukraine by 5.6 tons in terms of garbage per inhabitant, it is also one of the world leaders in waste recycling (Avfall, Sverige, 2019). According to the Avfall Sverige Re- cycling Association, about $49 \%$ of garbage was recycled and $50 \%$ of waste was burned for energy production in 2019 (Avfall Sverige, 2019). Besides, the association was organized back in 1947 and currently provides waste collection and recycling in all municipalities of Sweden. We consider this experience at the stage of the formation of a green economy to be valuable not only for Ukraine, since in addition to municipalities, the association also includes other local government organizations, municipal enterprises and regional waste disposal and recycling enterprises, as well as manufacturers, consultants and contractors engaged in this field. Thus, the state authorities, local government bodies, the business sector, which employs about $30 \%$ of the population, are engaged in solving the problem. Despite the fact that the Swedes began sorting garbage only in the late 90 s - later than other European countries - now separate waste collection for each resident of the country has become a normal thing, so it can be affirmed that the vast majority of the Swedish population is engaged in solving this problem.

SHW disposal is not decisive on a global scale - it is more a consequence than a cause. Therefore, in order to ensure the future for new generations, it is necessary to focus on environmental standards in construction already at the design stage of the object, which will have a positive effect on human health. As the events of 2019-2020 showed, associated with the coronavirus pandemic, there is an increase in demand for high-quality and safe green offices in the world. For example, in 2020 alone, the number of objects certified according to the WELL standard in Europe increased by $88 \%$, while in Ukraine, as of 2021 , there are several business centers and only one residential complex with a green construction and energy efficiency certificate BREEAM.

It should be noted that the coronavirus pandemic not only undermined the health of the world's population, but also had a negative impact on the economy, 
the consequences of which humanity has yet to resolve. In this regard, green measures aimed at economy growth recovery can provide countries with an opportunity to recover more effectively through a combination of economy growth recovery and job creation. According to one of the forecasts of the World Economic Forum, a green economy growth recovery could create up to 395 million jobs by 2030 (World Economic Forum, 2020). This allows us to speak of green economy as a vector of sustainable development.

The main reason for the low proportion of green buildings and structures in Ukraine is the high certification standards and a wide range of criteria that the objects must meet. This leads to an increase in the cost and, often, an increase in the construction time, which generally negatively affects the implementation of the concept of sustainability.

\subsubsection{Green marketing}

Another effective tool for implementing the Sustainable Development Goals based on a green economy is green marketing, which the authors understand as activities aimed at meeting current needs without compromising the ability of future generations to meet their needs.

In this regard, there is a need to add a sustainable marketing concept to the basic marketing concepts (the concept of improving production, the concept of improving goods, intensifying commercial efforts, pure marketing, social and ethical marketing, modern marketing concept), which not only allows achieving the market goal of the organization, but also using resources effectively and without losses. As the green economy develops, it should also be noted that there is a need to change the vector of the green marketing complex (marketing mix, $4 \mathrm{P}$ theory). Modern trends no longer allow talking about it from the position of the market supply of products that are environmentally friendly (Galkin A., Popova Y., Kyselov V., Kniazieva T., Kutsenko M., Sokolova N., 2020). Global challenges define the green marketing complex of 2021 as a market for sustainable and socially responsible products and services. For this purpose, the green marketing complex is focused on creating environmentally friendly products, using sustainable business practices, promoting the green advantages of existing products, using recycled materials in production, using green energy, reducing production waste, using environmentally friendly methods of buying or selling locally, reducing transport energy, reducing packaging, making reusable or recyclable products, etc.

As an example, let us consider the experience of Sweden again where the problem of plastic recycling is very acute. This is a problem not only for the Swedes, but also for the whole world, since the reuse of plastic, due to its composition, is possible only twice, and some types of plastic, due to the toxicity of some types thereof, will not be processed at all, respectively, the issue of its disposal is not removed from the agenda. This is where marketing comes to the rescue, or rather a of green marketing complex. For example, due to the communication component (promotion), it is possible to reduce the use of plastic packaging, by persuading the consumer through various media, ads, to abandon it in favor of paper, glass and other containers. So in Sweden, many stores have replaced plastic and polyethylene bags with paper ones. Several large grocery stores now offer special paper bags. Therefore, the package can be used twice. A special tax on plastic bags introduced this year also helped to reduce the use of plastic bags and raise awareness among Swedes. For regular plastic it is 3 crowns, for a thin one - 0.3 crowns (Miljönär, 2020).

In addition, one of the marketing tools on the way to sustainable consumption in Sweden is the Miljönär label, the application of which helps to attract attention to organizations that give society the opportunity to reuse, separate or reduce the volume of waste in any other way.

A similar goal is being implemented by the European Demolition Association, which includes 79 European companies and which, in addition to exchanging experience in the issues of demolition and disposal of SHW, uses green marketing techniques to popularize this area around the world, informing the public and the government about the need for recycling construction waste. In the UK, an important role is assigned to information technologies, namely, they print advertising and information catalogs of rural green tourism objects with a certified characteristic of the range of their services. This experience is valuable in the context of implementing the directions of the green economy as a vector of sustainable development.

\section{Conclusion}

As can be seen from the above, the formation of theoretical, methodological foundations and the development of conceptual approaches to the practical provision of the green economy, considered as a vector of sustainable development, was carried out on the basis of generalization of scientific points of view regarding the interpretation of such categories as economic growth, green economy, sustainable development.

It was proved that economic growth in the context of the formation of a holistic sustainable economic form that will allow bringing civilization to a new level of development should be understood as such growth, which is achieved not only through technology but, to a greater extent, through the use of human capital. It was proposed to consider the green economy as an engine of economic growth which determines the state of the triad of sustainable development and involves focusing efforts on the implementation of the Millennium Development Goals, which 
are the base for the 2015 Sustainable Development Goals.

The author's vision of economic growth in the context of sustainable development was formed, expressed in the form of a component model, which, unlike the existing ones, allows reflecting the essence and content of the green economy by combining the process and state, due to the fact that all components of sustainable development and the green economy are in constant dynamics and interaction. The presented model is the basis for further research, namely, the classification of indicators of the green economy.

By generalizing the positive experience of green integration on the example of green tourism, green construction and green marketing, the need for a differentiated approach to the practical implementation of the Millennium Development Goals was justified.

\section{References}

1. A guidebook to the Green Economy. Issue 1: Green Economy, Green Growth, and Low-Carbon Development - history, definitions and a guide to recent publications, 2011, https://sustainabledevelopment.un. org/content/documents/GE\%20Guidebook.pdf (07.03.2021).

2. American agency $24 / 7$ Wall Street, 2019, https://247wallst.com/infrastructure/ (21.07.2021).

3. Avfall Sverige, 2019, https://www.avfallsverige.se/ (23.07.2021).

4. BOBYLEV S.N., 2019, New models of the economy and indicators of sustainable development, Economic revival, 61(3): 23-29.

5. BOICHENKO E., MARTYNOVYCH N., SHEVCHENKO I., 2021, Cognitive modeling concepts of sustainable development of society, Problemy Ekorozwoju/ Problems of Sustainable Development, 16(2):159-165.

6. BP Statistical Review of World Energy, 2020,

7. BRUNNER K., 1961, The report of the Commission on Money and Credit, Journal of Political Economy, 69(Dec.): 605-20.

8. Building an Equitable Green Economy, 2013, http://www.92grp.dk/files/fokus-og-nyheder/07-TA RA.pdf (13.06.2021)

9. California Department of Resources Recycling and Recovery, 2020, https://calrecycle.ca.gov/

(06.08.2021)

10. Cambridge Dictionary online, https://dictionary.cambridge.org/ (03.06.2021).

11. Desk Studies (UNDS), Assessing the Potential of Countries in Eastern Europe, Caucasus and Central Asia in the Development of Statistics to Measure Sustainable Development and Environmental Sustainability, 2020, https://unece.org/fileadmin/DAM/stats/ (19.07.2021).

12. Directive 2008/98/EC of the European Parliament and of the Council of 19 Nov 2008 on waste and repealing certain Directives, https://eur-lex.europa.eu/ legal-content/ (16.07.2021).

13. UN Draft Resolution, The Future We Want, 2012, https://undocs.org/ru/A/66/L.56 (09.08.2021).

14. ERKER P., 2004, Vom nationalen zum globalen, Schoeningh Ferdinand GmbH, Paderborn.

15. European Federation of Farm and Rural Tourism EuroGites, 2020, https://nexttourismgeneration.eu/ research/ (24.07.2021).
16. Eurostat, 2021, Generation of waste excluding major mineral wastes by hazardousness, https://ec.europa.e u/eurostat/databrowser/view/sdg_12_50/default/tabl e?lang=en (04.08.2021)

17. France Report on Measuring Economic Performance and Social Progress, 2011, https://unstats.un.org/unsd/statcom/doc11/2011-35-FranceR.pdf (11.07.2021).

18. FRIEDMAN M., SCHWARTZ A., 1963, The Monetary History of the United States, 1867-1960, Princeton University Press, New Jersey.

19. GALKIN A., POPOVA Y., KYSELOV V., KNIAZIEVA T., KUTSENKO M., SOKOLOVA N., 2020 Comparison of Urban Conventional Delivery and Green Logistics Solutions, 13th International Conference on Developments in eSystems Engineering (DeSE): 95-99.

20. Green Economy, Green Technologies Kazakhstan, https://www.youtube.com/watch?v=s CIX1NikYmQ (12.08.2021)

21. Green economy transition approach, 2013, https:// www.google.com/ (24.06.2021).

22. Group ICS, 2021, https://www.icsgroup.ru/green/ ecostandards/ (21.07.2021).

23. GUTENBERG A. W., 1955, The Economics of the Evaporative Cooler Industry in the Southwestern United States, Stanford University Graduate School of Business, Stanford.

24. ICC comments on the UNEP draft Green Economy Report, 2012, https://cdn.iccwbo.org/content/uploads/sites/3/2011/05/ICC-comments-on-the-UNEPdraft-Green-Economy-Report.pdf (24.06.2021).

25. IFC World Bank Group, 2021, https://documents1.worldbank.org/curated/ (16.07.2021).

26. Miljönär, 2020, https://xn--miljnr-fua6l.se/ (06.08.2021)

27. OECD, 2021, https://www.oecd.org/ (12.07.2021).

28. PEARCE D., BARBIER E., MARKANDIA A., 1991, Reviewed Work: Sustainable Development: Economics and Environment in the Third World, Weltwirtschaftliches Archiv, Springer: 414-416.

29. Property Times, 2018, https://propertytimes.com.ua/ spetsproekti/stroitelnye_othody_kto_kak_i_kuda_vy vozit_musor_s_kievskih_stroek (09.07.2021).

30. RAWORTH K., 2019, Doughnut Economics: Seven Ways to Think Like a 21st-Century Economist, Our Format, Kiev.

31. Reuters, 2021, https://www.reuters.com/ (11.07.2021)

32. Synthesis report for representatives of the authorities in Nairobi, 2011, http://www.un.org/ru/development/sustainable/ger_synthesis.pdf (24.06.2021).

33. The green economy: trade and sustainable development implication, 2011, http://unctad.org/en/docs/ ditcted20102_en.pdf (24.06.2021).

34. Transport Infrastructure Design Institute, 2020, https://ipit.ooo/ru/the-use-of-waste-in-construction (11.07.2021)

35. UN Environment Program, 2020, Six Ways Nature Can Protect Us From Climate Change https://www.unep.org (17.08.2021).

36. UNEP, 2009, Green Economy Initiative. Linkages to Sustainable Consumption and Production, http://www.unep.fr/scp/marrakech/pdf/SCPGE\%20 Workshop\%20presentation\%20Steven\%20Stone.pdf

37. UNWTO, 2021, https://www.unwto.org/ru (14.08.2021)

38. WTTC, 2021, https://wttc.org/ (11.07.2021).

39. World Economic Forum, 2020, The Future of Nature and Business, http://www3.weforum.org/ docs/WEF _The_Future_Of_Nature_And_Business_2020.pdf (04.09.2021) 